\title{
Stress Distribution and Failure Characteristics of Stope Overburden of an Inclined Coal Seam
}

\author{
Xin Liu, Jian Sun $(\mathbb{D}$, and Yong Yang \\ State Key Laboratory of Mining Response and Disaster Prevention and Control in Deep Coal Mines, Anhui University of Science \\ and Technology, Huainan 232001, China
}

Correspondence should be addressed to Jian Sun; sj323@cumt.edu.cn

Received 25 February 2021; Accepted 9 November 2021; Published 8 December 2021

Academic Editor: Yi Xue

Copyright (C) 2021 Xin Liu et al. This is an open access article distributed under the Creative Commons Attribution License, which permits unrestricted use, distribution, and reproduction in any medium, provided the original work is properly cited.

\begin{abstract}
The stress distribution, failure depth, and shape and range of overlying strata of the stope are important bases for the prevention of roof water hazards and determination of reasonable locations of roof roadways. Based on the hydrogeological data of the E9103 workface, FLAC numerical simulation software was used to establish a numerical calculation model of the overlying strata of the E9103 inclined coal seam, and the stress distribution and failure characteristics of the overlying strata were analyzed. The development height of the caving and water-flowing fractured zones in the overlying strata of the workface was determined. Results showed that the stress reduction area appeared above the goaf in the form of an "arched" distribution, and tensile stress occurred in the local area of the overburden. The overburden relief arch of the workface was symmetrically distributed along the advanced direction and asymmetrically distributed along the inclined direction, with the arch crown deflecting above the workface. The horizontal and vertical displacements of the overlying strata of the stope increased with the advancing distance of the workface. The horizontal displacement in the $x$-direction presented two obvious regions, and the critical points of the two regions moved forward with the advancement of the workface and showed a certain degree of symmetry. The horizontal displacement in the $y$-direction presented an "inverted bowl" distribution and increased with the advancement of the workface. The main failure forms of the overlying strata of the workface were a tensile and shear failure, and shear failure was dominant in the upper direction. The height of the overburden caving zone in the workface had little relationship with the advancing distance of the workface and increased slowly as the advancing distance of the workface increased. The development height of the caving zone is $7.2-18.13 \mathrm{~m}$. The development height of the water conduction fissure zone increased rapidly with the increase in the advancing distance of the workface. When the advancing distance was equal to the length of the workface, the development height of the water conduction fissure zone was flat and basically maintained at a stable value. The development height of the water conduction fissure zone is $30.8-62.2 \mathrm{~m}$. These research findings have important engineering importance for ensuring safe and efficient mining of E9103 workface.
\end{abstract}

\section{Introduction}

Coal seam mining destroys the original stress balance state of overburden strata; causes stress redistribution in the surrounding rocks of the stope; forms stress concentration and stress reduction areas; leads to the deformation, movement, separation, fracture, and collapse of overburden strata in the stope; and results in caving zone, water conduction fissure zone, and bending zone [1-5]. Determining the development height of the caving and water conduction fissure zones of a mining workface is conducive to predicting and preventing roof water disasters when the confined aquifer and water accumulate in the goaf in the overlying strata of a coal seam [6-8]. Therefore, research on the stress distribution, failure characteristics, and influence range of overlying strata is the premise and basis for realizing safe mining under confined water, determining the reasonable position of roof roads, and judging the influence of lower coal mining on upper coal mining [9-13].

At present, research on the stress distribution and failure characteristics of overlying strata of stope mainly involves numerical simulation, similar simulation, and field 


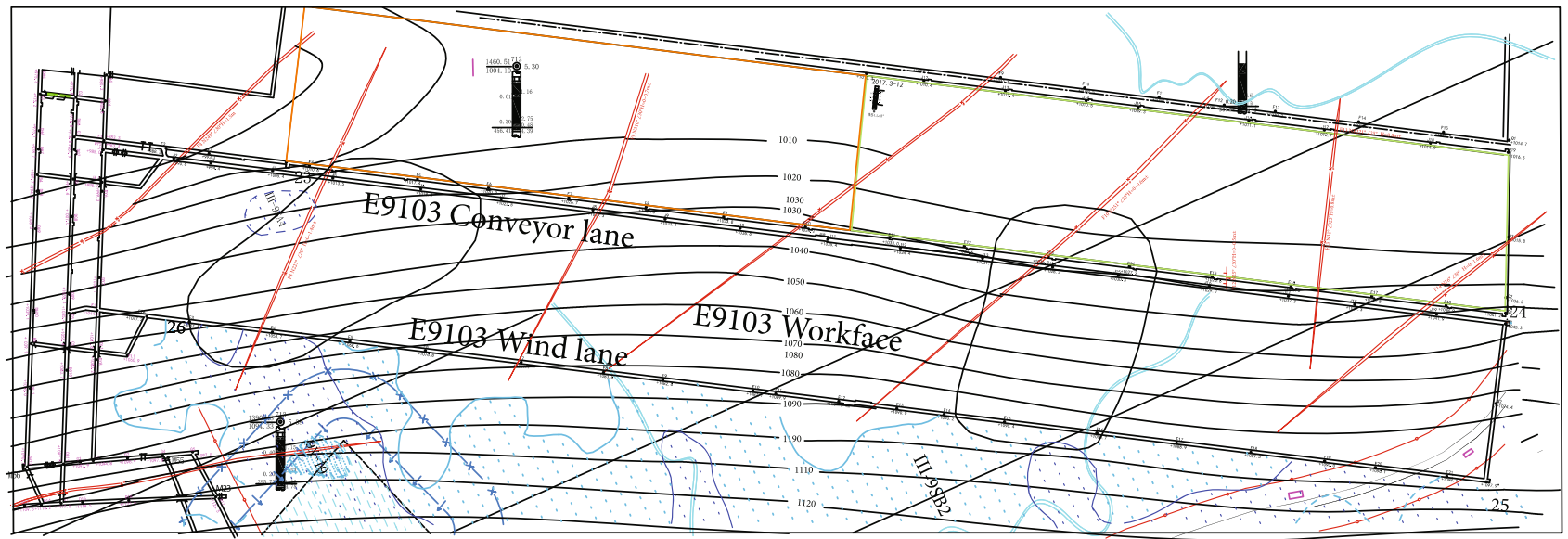

Figure 1: Plan of E9103 workface.

monitoring. These methods provide technical support and safety guarantee in realizing safe mining under confined water, determining the reasonable position of roof roads, and judging the influence of lower coal mining on upper coal mining. Wang et al. [14] studied the dynamic evolutionary characteristics and spatiotemporal coupling effect of mining pressure, strata movement, and fracture distribution in a deep stope by using comprehensive methods composed of numerical simulation, similar simulation, and field monitoring. The dynamic response mechanism of mining stress, overlying strata displacement, and roof fracture fields has also been investigated. To obtain the reasonable position of roadways in the upper coal seam, Huang et al. [15] studied the morphology characteristics of the fractured zone and the concentrated stress distribution in surrounding rock induced by the mining of the lower coal seam by using theoretical analysis, field testing, and numerical simulation. They proposed two schemes for roadway positions, namely, inner and outward stagger modes, and avoided the influence of the fractured zone and concentrated stress field effectively. Based on the engineering background of Dananhu No. 1 Coal Mine in Xinjiang, Lai et al. [16] studied the overburden fracture and water conduction characteristics of fully mechanized top coal caving mining in a soft roof-coal-floor coal seam under an extremely arid climate. Their research provided a scientific basis for the safe mining of fully mechanized top-coal caving workface in soft roof-coal-floor coal seams and the determination of proper water-retaining mining schemes. Yang et al. [17] used the 11915 workface of a mine as an example and applied three methods, namely, borehole water leakage, borehole TV, and numerical simulation, to observe the height of the water conduction zone.

The abovementioned research results play an effective guiding role in ensuring the safety of coal mine production. Based on the engineering background of E9103 workface mining in Linfen Tianyu Hengjin Coal Mine and the hydrogeological data of the workface, a numerical calculation model of mining overburden in the E9103 inclined coal seam workface was established through FLAC numerical simulation software in this study. The stress distribution, failure characteristics, and development height of the overburden caving and water conduction fissure zones were simulated and analyzed. The research results have important engineering guiding significance for ensuring safe and efficient mining of the E9103 workface.

\section{Numerical Calculation Model of the Mining Overburden of an Inclined Coal Seam}

2.1. Engineering Background. Linfen Tianyu Hengjin Coal Mine of Anhui Wanbei Coal Electricity Group mainly mines nos. 9 and 10 coal seam. The E9103 workface is the second fully-mechanized top-coal caving workface in the first east mining area of the mine. The workface is located in the east wing of the Nanshan inclined shaft, and the cut hole is constructed close to the protective coal pillar line of the mining boundary. The outer horizontal distance of the machine lane is $8 \mathrm{~m}$ from the E9101 workface goaf, and the outer side of the wind lane is the solid coal that has not yet been mined. The line is estimated to be $197 \mathrm{~m}$ away from Dongyi transportation uphill. The length of the transportation roadway is $1718 \mathrm{~m}$. The ventilation roadway is $1739 \mathrm{~m}$ long and $190 \mathrm{~m}$ wide on the average in the E9103 workface. The coal seam floor elevation of the workface is $+1015 \mathrm{~m}$ to $+1117 \mathrm{~m}$, the average thickness of the coal seam is $4.50 \mathrm{~m}$, the inclination angle of the coal seam is $14^{\circ}$ to $18^{\circ}$, and the average inclination is $16^{\circ}$, as shown in Figure 1 . The immediate roof and the main roof of the E9103 workface are shallow marine limestone with high compressive strength (the average compressive strength is $29.6 \mathrm{MPa}$ ), which makes it difficult for the roof to fall. The immediate floor of the E9103 workface is made up of mudstone, no. 11 coal seam, mudstone, and limestone.

The no. 2 coal seam above the E9103 workface has been mined. Water accumulation in the goaf and the roof sandstone aquifer (K5, K7, and no. 2 coal roof sandstone aquifer) are the main sources of water inrush to the workface. If the water conduction fissure zone communicates with the water accumulated in the goaf and aquifer of roof sandstone after the E9103 workface is mined, the safe production of the mine will be threatened. To ensure normal and safe mining, the stress distribution and failure characteristics of the 

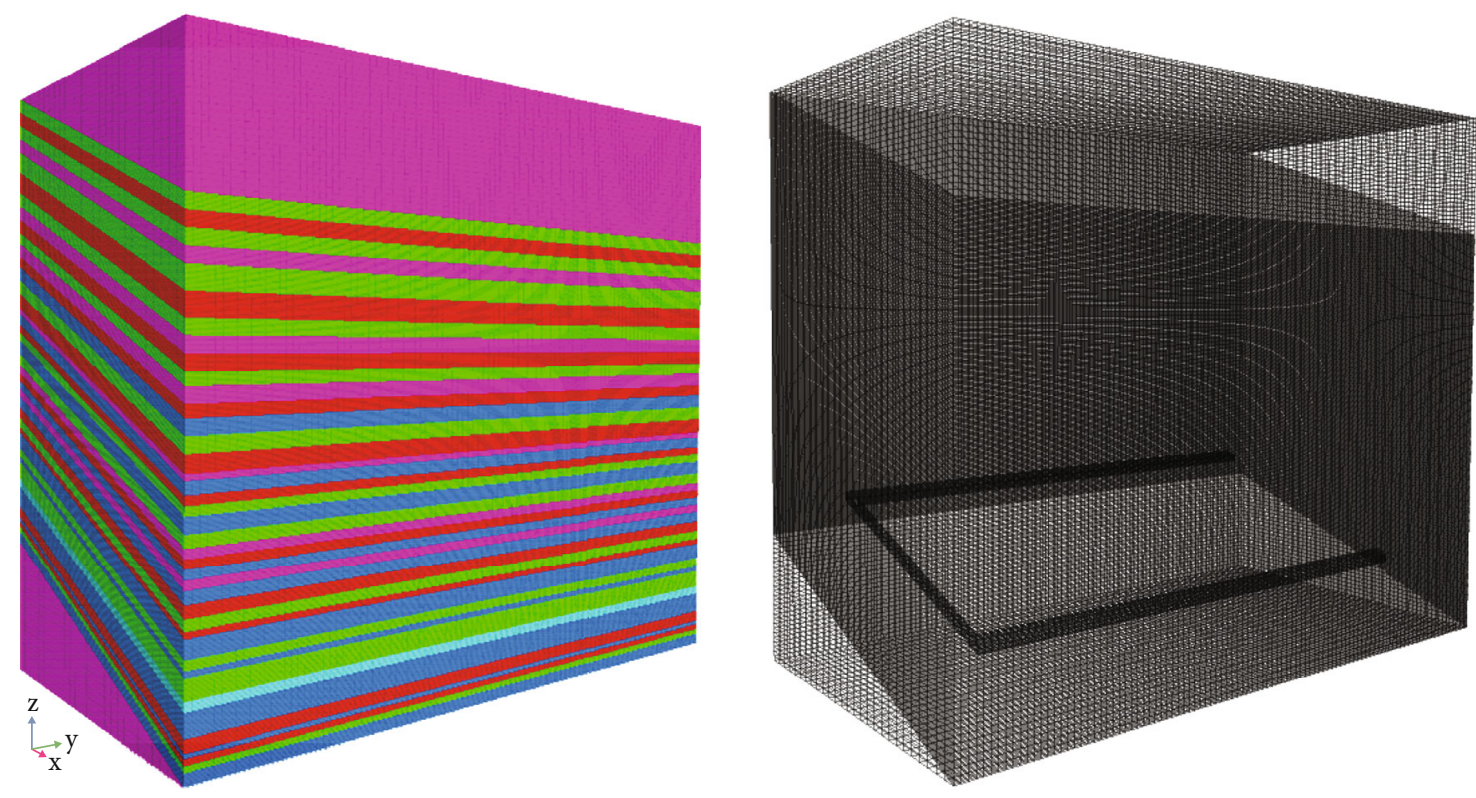

Figure 2: Numerical calculation model of E9103 workface.

overlying strata in the E9103 workface must be studied, the development height of the water conduction fissure zone must be determined, and corresponding technical measures should be formulated for water hazard prevention and control in accordance with the existing geological and hydrological data of the mine. Doing so will guarantee safe and efficient production of the mine.

2.2. Computational Models and Simulation Parameters. Based on the comprehensive geological histogram of the E9103 workface of Hengjin Coal Mine, a numerical calculation model of the overlying strata of an inclined coal seam was established, as shown in Figure 2. In the model, the $x$-direction is the inclined direction of the workface, the $y$-direction is the strike direction, the inclined length ( $x$-direction) is $300 \mathrm{~m}$, and the strike length ( $y$-direction) is $500 \mathrm{~m}$. The inclination angle of the rock and coal seam is $16^{\circ}$, and $50 \mathrm{~m}$ coal pillars are set around the workface. Excavation is carried out from $y=50 \mathrm{~m}$ and stopped at $y=450 \mathrm{~m}$, with a total of $400 \mathrm{~m}$ forward excavation. The bottom surface of the model constrains the displacement in the vertical direction, and the front and rear sides restrain the displacement in the horizontal direction. The upper surface of the model is a free surface, and the overlying strata (except the coal seam roof) are loaded to the upper surface of the model in the form of uniform load (applied load of 8.2 $\mathrm{MPa}$ ). The physical and mechanical parameters of the roof and floor of the inclined coal seam workface in the model are shown in Table 1.

During model calculation, the calculation grid is divided according to the geometric size of the model, and the corresponding physical and mechanical parameters are provided to the rock layer. Then, the stress equilibrium state of the original rock of the model is calculated. The model is excavated step by step with $20 \mathrm{~m}$ excavation per step and 20 excavations in total at one time. The movement, deformation, and failure laws of the overlying strata of the E9103 workface are simulated under different driving distances. At the end of each excavation calculation, the information of the simulation unit and the joint is extracted to analyze the change rule of the stress distribution and failure characteristics of the overlying strata of E9103 workface with the advancing distance of the workface and to reveal the evolution rule of the overburden movement and development height of the water conduction fissure zone in E9103 workface.

2.3. Constitutive Model and Coal-Rock Parameters. The approximate ideal elastic-plastic model is used for the numerical calculation model, and Mohr-Coulomb yield criterion is adopted for the failure criterion. The MohrCoulomb yield criterion can be expressed as follows:

$$
\left\{\begin{array}{l}
f^{s}=\sigma_{1}-\sigma_{3} N_{\varphi}+2 C \sqrt{N_{\varphi}} \\
f^{t}=\sigma_{3}-\sigma^{t}
\end{array}\right.
$$

where $\sigma_{1}$ and $\sigma_{3}$ are the maximum and minimum principal stresses, respectively; $C$ and $\varphi$ are the cohesive force and internal friction angle, respectively; $\sigma^{t}$ is the tensile strength of the material; $\sigma_{\max }^{t}=c / \tan \varphi$; and $N_{\varphi}=1+\sin \varphi / 1-\sin \varphi$. When $f^{s}=0$, the material undergoes shear failure, and when $f^{t}=0$, the material undergoes tensile failure.

The physical and mechanical parameters of coal and rock mass involved in the elastic-plastic model of the Mohr-Coulomb yield criterion include bulk modulus $B$, shear modulus $S$, cohesion $C$, internal friction angle $\varphi$, and mass density $D$. $B$ and $S$ are determined according to elastic 
TABLE 1: Physical and mechanical parameters of roof and floor of E9103 workface.

\begin{tabular}{|c|c|c|c|c|c|c|c|c|}
\hline No. & Lithology & $\begin{array}{l}\text { Thickness } \\
(\mathrm{m})\end{array}$ & $\begin{array}{l}\text { Density } \\
\left(\mathrm{kg} \cdot \mathrm{m}^{-3}\right)\end{array}$ & $\begin{array}{l}\text { Bulk modulus } \\
\qquad(\mathrm{GPa})\end{array}$ & $\begin{array}{l}\text { Shear modulus } \\
(\mathrm{GPa})\end{array}$ & $\begin{array}{c}\text { Tensile strength } \\
(\mathrm{MPa})\end{array}$ & $\begin{array}{c}\text { Cohesion } \\
(\mathrm{MPa})\end{array}$ & $\begin{array}{c}\text { Internal friction } \\
\text { angle }\left({ }^{\circ}\right)\end{array}$ \\
\hline 1 & Medium sandstone & 44.0 & 2650 & 2.21 & 1.15 & 2.4 & 2.50 & 32 \\
\hline 2 & Fine sandstone & 9.5 & 2620 & 1.93 & 1.00 & 2.20 & 2.78 & 36 \\
\hline 3 & Siltstone & 4.0 & 2650 & 2.08 & 1.33 & 1.84 & 2.55 & 37 \\
\hline 4 & Fine sandstone & 8.0 & 2650 & 1.93 & 1.00 & 2.20 & 2.78 & 36 \\
\hline 5 & Mudstone & 5.0 & 2650 & 1.78 & 0.92 & 0.88 & 1.84 & 29 \\
\hline 6 & Siltstone & 4.0 & 2650 & 2.08 & 1.33 & 1.84 & 2.55 & 37 \\
\hline 7 & Mudstone & 6.0 & 2650 & 1.78 & 0.92 & 0.88 & 1.84 & 29 \\
\hline 8 & Siltstone & 9.0 & 2650 & 2.08 & 1.33 & 1.84 & 2.55 & 37 \\
\hline 9 & Coal seam & 4.5 & 1400 & 1.51 & 0.77 & 0.65 & 1.90 & 25 \\
\hline 10 & Mudstone & 4.0 & 2650 & 1.78 & 0.92 & 0.88 & 1.84 & 29 \\
\hline 11 & Fine sandstone & 7.0 & 2650 & 1.93 & 1.00 & 2.20 & 2.78 & 36 \\
\hline 12 & Mudstone & 3.0 & 2650 & 1.78 & 0.92 & 0.88 & 1.84 & 29 \\
\hline 13 & Fine sandstone & 6.0 & 2650 & 1.93 & 1.00 & 2.20 & 2.78 & 36 \\
\hline 14 & Siltstone & 6.0 & 2650 & 2.08 & 1.33 & 1.84 & 2.55 & 37 \\
\hline 15 & Mudstone & 3.0 & 2650 & 1.78 & 0.92 & 0.88 & 1.84 & 29 \\
\hline 16 & Medium sandstone & 20.0 & 2650 & 2.21 & 1.15 & 2.4 & 2.50 & 32 \\
\hline
\end{tabular}

modulus $E$ and Poisson ratio $\mu$ of coal and rock mass, and the relationships between them are as follows:

$$
\left\{\begin{array}{l}
B=\frac{E}{3(1-2 \mu)}, \\
S=\frac{E}{2(1+\mu)} .
\end{array}\right.
$$

\section{Stress Distribution of Overlying Strata under Mining in an Inclined Coal Seam}

After coal seam mining, the overlying strata moved and deformed, resulting in stress redistribution and the emergence of pressure phenomena in the workface. Figure 3 shows a cloud diagram of the vertical stress distribution of the overlying strata of E9103 workface at different advancing distances. Correspondingly, Figure 4 shows the variation rule of the vertical stress concentration coefficient with the change of advancing distance. The excavation of the workface destroys the stress balance state of the original rock, resulting in the stress redistribution of the stope surrounding rock and the formation of mining disturbance. The change in advancing distance reflects different disturbance and destruction ranges of the overburden coal and rock mass caused by coal seam mining.

When the workface is pushed forward for $40 \mathrm{~m}$, stress concentration occurs in the coal and rock mass in the front and rear of the workface. The peak vertical stress in front of the workface reaches $14.38 \mathrm{MPa}$, and the stress concentration coefficient is 1.78 (Figure 4). Meanwhile, a stress reduction area appears above the goaf of the workface in the form of an "arch" distribution, and tension stress occurs in the local area of the overburden layer. The occurrence of tensile stress, which causes macrotensile damage to the roof of the goaf, is the dominant factor for the collapse and destruction of overlying strata and the main reason for the development of fracture and fissure in the lower part of the fissure zone. With the increase in the advancing distance in the workface, the mining disturbance range is enlarged continuously, and the low-stress area above the goaf develops upward in the form of an "arch." When the workface is pushed to $200 \mathrm{~m}$, the peak bearing pressure at the rear of the workface reaches the maximum value of $21.01 \mathrm{MPa}$, and the stress concentration factor is 2.6 (Figure 4). As the workface continues to advance, the increasing trend of peak bearing pressure gradually slows down, as shown in Figures 3(f)-3(j). This result indicates that the mine pressure is relatively obvious during the first meeting period of the workface. It also suggests that safe production, such as roof management during the first meeting period and its following period, should be strengthened when the workface is recovered.

Figure 5 shows a cloud diagram of the vertical stress distribution of the overlying strata in the workface along the inclined direction of the coal seam during the advancing process of the E9103 workface (200 and $400 \mathrm{~m}$ ). The distribution characteristics of the vertical stress field of the overlying strata in the workface at different positions along the inclined direction of the coal seam are similar to those along the strike direction of the workface. Stress concentration areas occur in the coal and rock mass in front of and behind the workface, and stress reduction areas occur in the goaf area of the workface and gradually develop upward in the form of an "arch." Figure 5 shows that with the advancing of the workface, the mining space gradually forms, the overlying strata of the workface move and are destroyed under the action of gravity, the immediate roof directly falls down, and the main roof breaks, resulting in mining failure crack and the redistribution of the overlying strata of the workface. The relief arch of the overlying strata basically shows a 


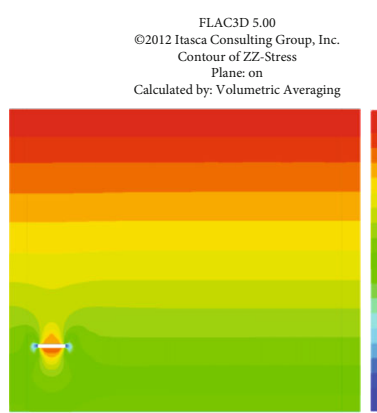

(a) $40 \mathrm{~m}$

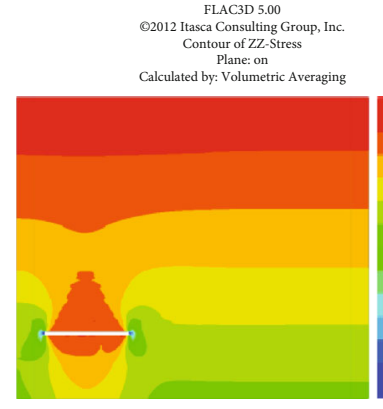

(c) $120 \mathrm{~m}$

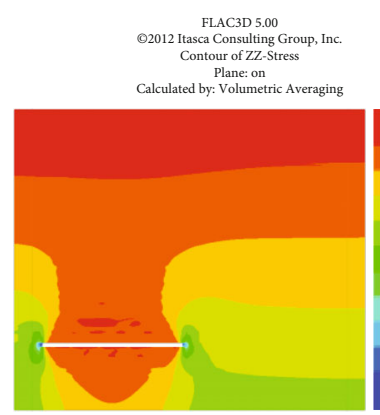

(e) $200 \mathrm{~m}$

FLAC3D 5.00

Q2012 Itasca Consulting Group,
Contour of ZZ-Stress

Plane: on
Calculated by: Volumetric Averaging

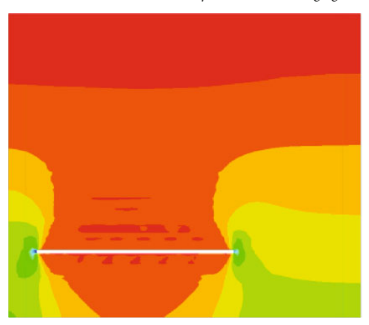

(g) $280 \mathrm{~m}$

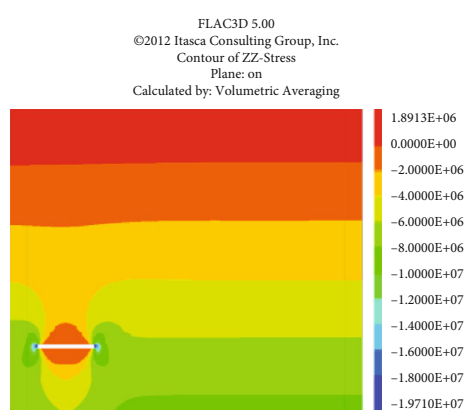

(b) $80 \mathrm{~m}$

FLAC3D 5.00 Itasca Consulting Group, Inc.
Contour of ZZ-Stress Plane: on
ulated by: Volumetric Averaging

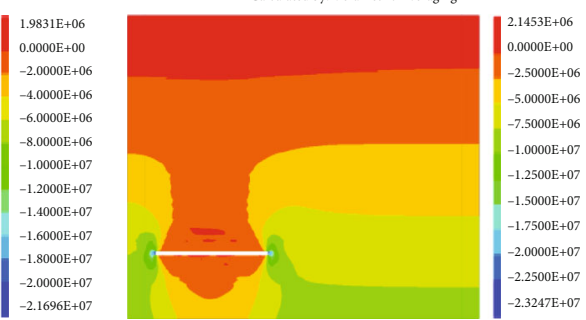

(d) $160 \mathrm{~m}$

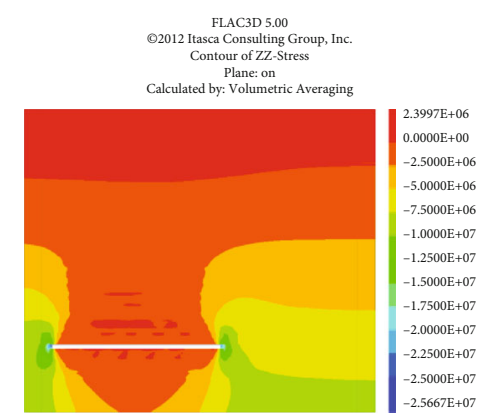

(f) $240 \mathrm{~m}$

FLAC3D 5.00 2012 Itasca Consulting Group, Inc.
Contour of ZZ-Stress Plane: on
Calculated by: Volumetric Averaging \begin{tabular}{|l}
$2.3999 \mathrm{E}+07$ \\
$0.0000 \mathrm{E}+00$ \\
$-2.5000 \mathrm{E}+06$ \\
$-5.0000 \mathrm{E}+06$ \\
$-7.5000 \mathrm{E}+06$ \\
$-1.0000 \mathrm{E}+07$ \\
$-1.2500 \mathrm{E}+07$ \\
$-1.5000 \mathrm{E}+07$ \\
$-1.7500 \mathrm{E}+07$ \\
$-2.0000 \mathrm{E}+07$ \\
$-2.2500 \mathrm{E}+07$ \\
$-2.5000 \mathrm{E}+07$ \\
$-2.6487 \mathrm{E}+07$
\end{tabular}

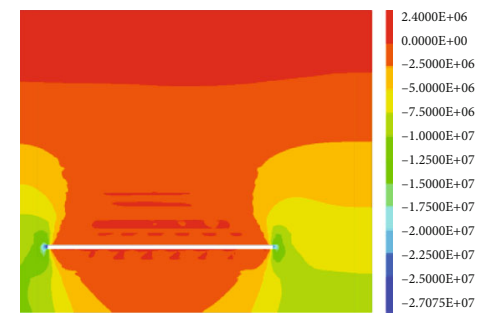

(h) $320 \mathrm{~m}$

FIgUre 3: Continued. 


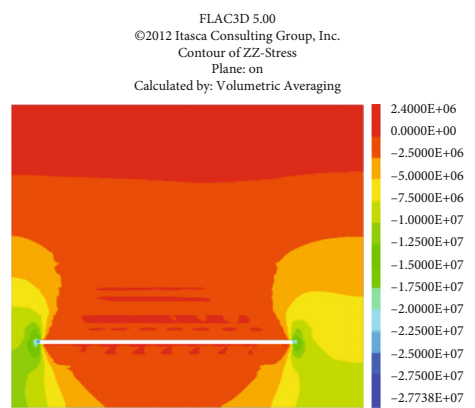

(i) $360 \mathrm{~m}$

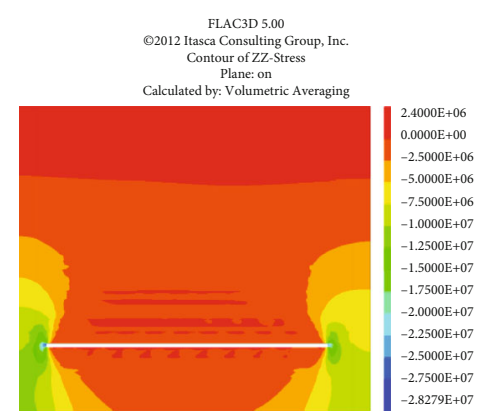

(j) $400 \mathrm{~m}$

FIgURE 3: Cloud diagram of vertical stress distribution of overlying strata of E9103 workface at different advancement distances.

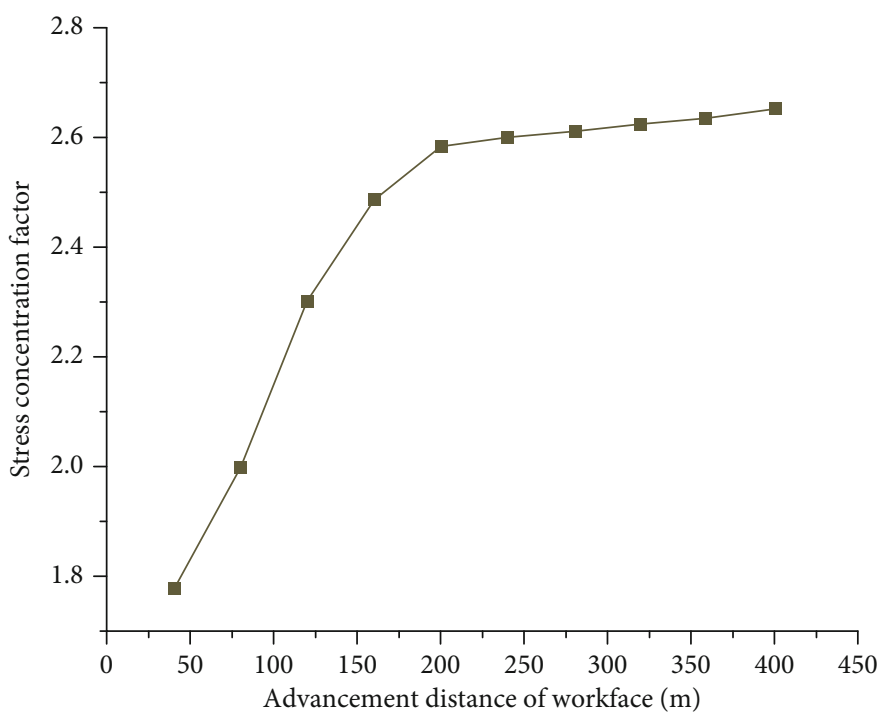

FIGURE 4: Variation regularity of vertical stress concentration coefficient of overlying strata of E9103 workface at different advancement distances.

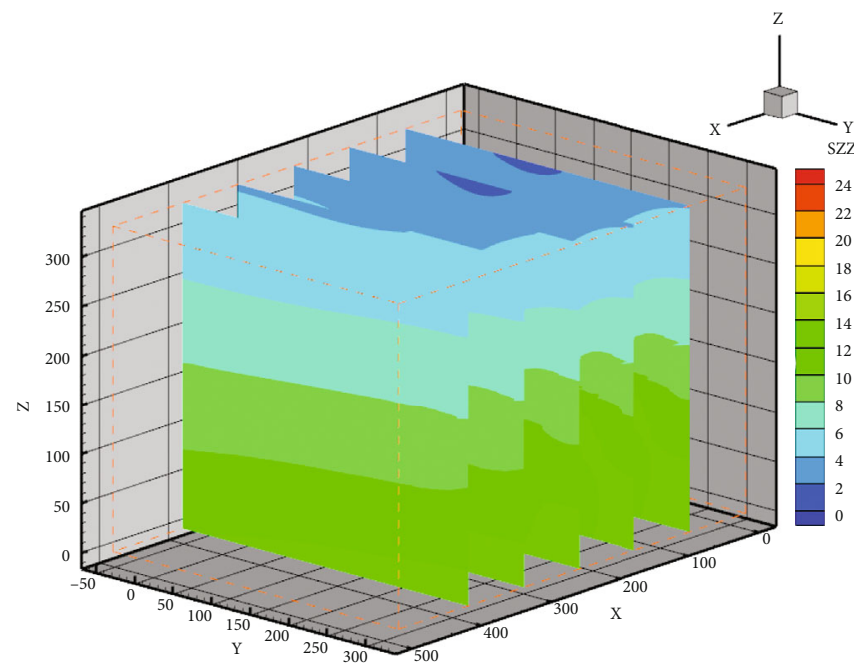

(a) $200 \mathrm{~m}$

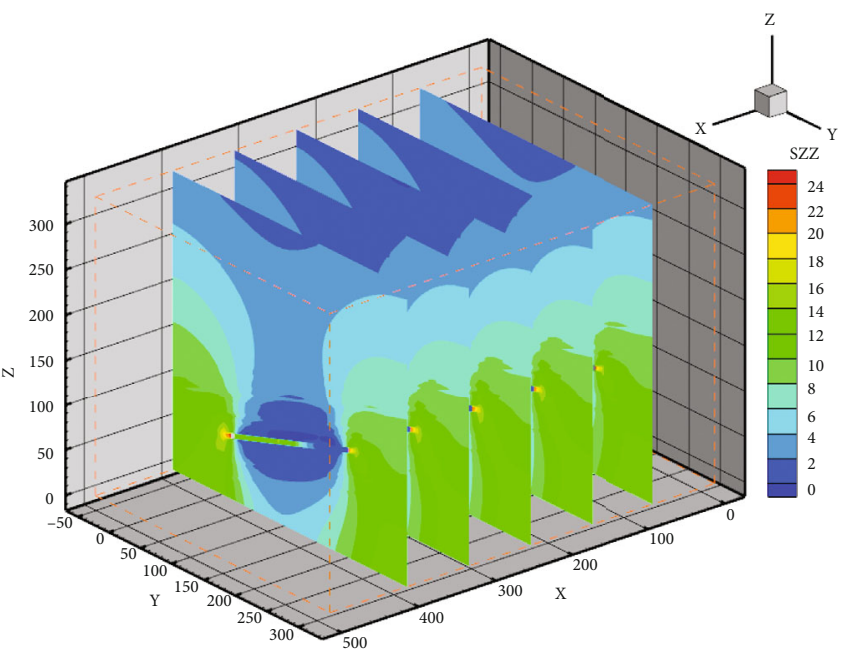

(b) $400 \mathrm{~m}$

Figure 5: Cloud diagram of vertical stress distribution of overlying strata of workface along the inclined direction of coal seam during advancing process $(200 \mathrm{~m}$ and $400 \mathrm{~m})$. 


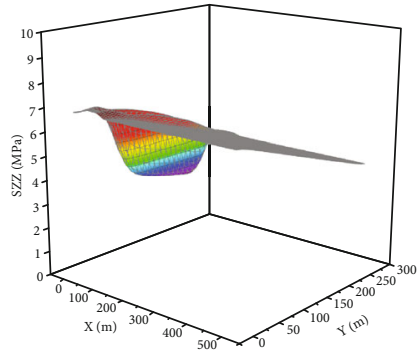

(a) $40 \mathrm{~m}$

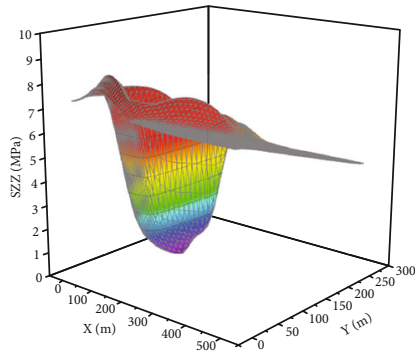

(c) $120 \mathrm{~m}$

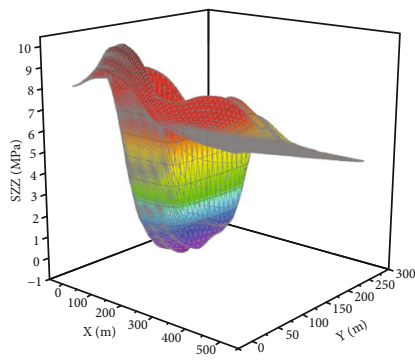

(e) $200 \mathrm{~m}$

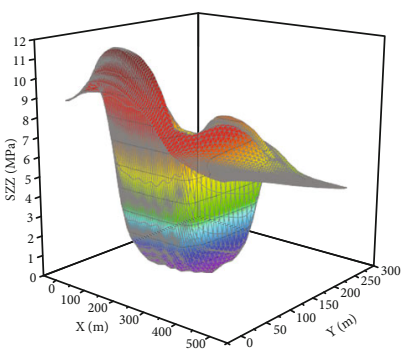

(g) $280 \mathrm{~m}$

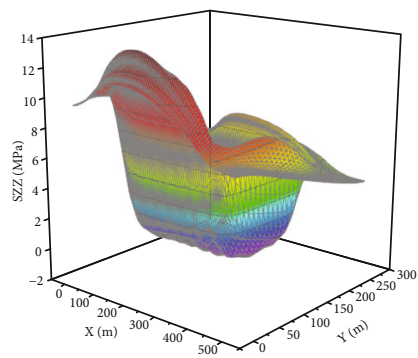

(i) $360 \mathrm{~m}$

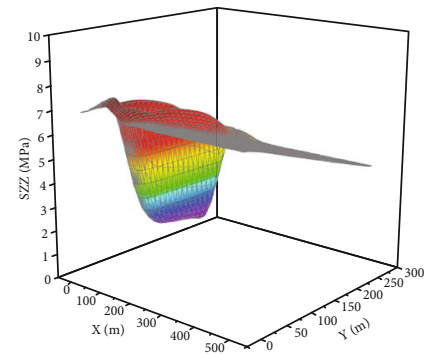

(b) $80 \mathrm{~m}$

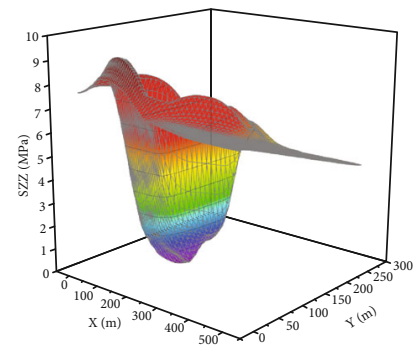

(d) $160 \mathrm{~m}$

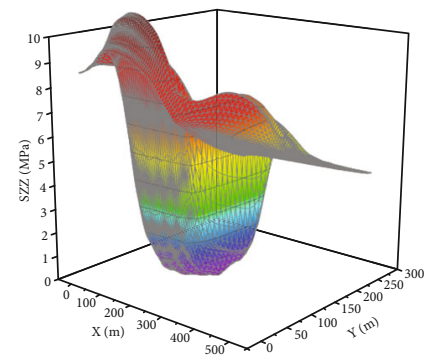

(f) $240 \mathrm{~m}$

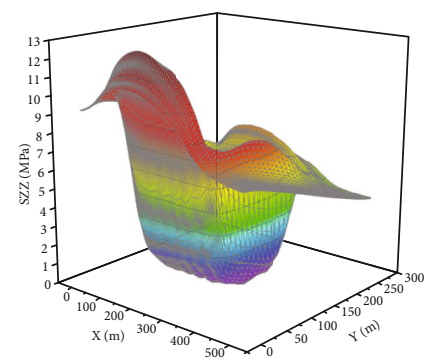

(h) $320 \mathrm{~m}$

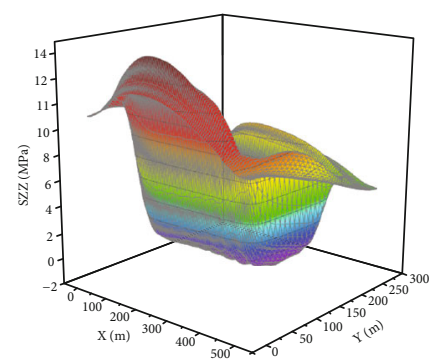

(j) $400 \mathrm{~m}$

FIGURE 6: Three-dimensional surface diagram of vertical stress of surrounding rock of E9103 workface at different advancement distances.

symmetrical distribution along the advancing direction of the workface, whereas the relief arch of the overlying strata presents an asymmetrical distribution along the inclined direction of the workface, and its vault is inclined above the workface. The stress distribution of the overlying strata of the stope along the inclined direction of the coal seam is 
completely different from that of the overlying strata of the workface of the horizontal coal seam.

Figure 6 shows a 3D surface diagram of the vertical stress of the surrounding rock of E9103 workface at different advancing distances. Correspondingly, Figure 7 shows a curve of the vertical stress of the surrounding rock of the E9103 workface with advancing distance of the workface. The stress of the surrounding rock changes with the increase in the advancing distance after the E9103 workface is mined, and areas of stress increase and decrease emerge to some extent. Local tensile stress occurs in the goaf area, leading to tensile failure of coal and rock mass and fracture.

\section{Displacement Characteristics of the Mining Overburden of an Inclined Coal Seam}

Figure 8 shows the vector distribution of the displacement of the overlying strata when the E9103 workface is pushed to $400 \mathrm{~m}$. The overlying strata of the stope move and deform with the advancement of the workface. The roof strata in the goaf move toward the goaf continuously, forming the subsidence area of the overlying strata, and the movement direction of the underlying floor strata in the goaf is opposite to that of the roof strata, forming a bottom drum area. The displacement vector value of the overlying roof and underlying floor strata in the goaf decreases with the increase in the distance from the goaf.

Figure 9 shows the variation curves of the horizontal displacement ( $x$ and $y$ directions) and vertical displacement ( $z$ direction) of the overburden of E9103 workface with different advancing distances. The horizontal and vertical displacements of the overlying strata of the stope increase with the advancing distance of the workface. Figure 9(a) indicates that the horizontal displacement in the $x$-direction presents two obvious areas. The horizontal movement direction of the overlying strata in a certain distance ahead of the open-off cut is consistent with the advancing direction of the workface (the $x$-direction displacement is greater than zero), whereas the horizontal movement direction of the overlying strata in a certain distance behind the stopping line is opposite to the advancing direction of the workface (the $x$-direction displacement is less than zero). With the increase in the advancing distance of the workface, the critical point of the domain ( $x$-direction displacement equals zero) moves forward constantly, presenting certain symmetry. Figure 9(b) shows that the horizontal displacement in the $y$-direction presents a distribution pattern of an "inverted bowl." The distribution is symmetrical in the central position of the goaf. With the continuous advancement of the workface, the horizontal displacement in the $y$-direction increases continuously, which may conducive to the formation of the failure fissures of the overlying strata. Figure 9(c) indicates that the vertical displacement of the overlying strata of the stope increases continuously with the advancement of the workface, and the influence range increases continuously.

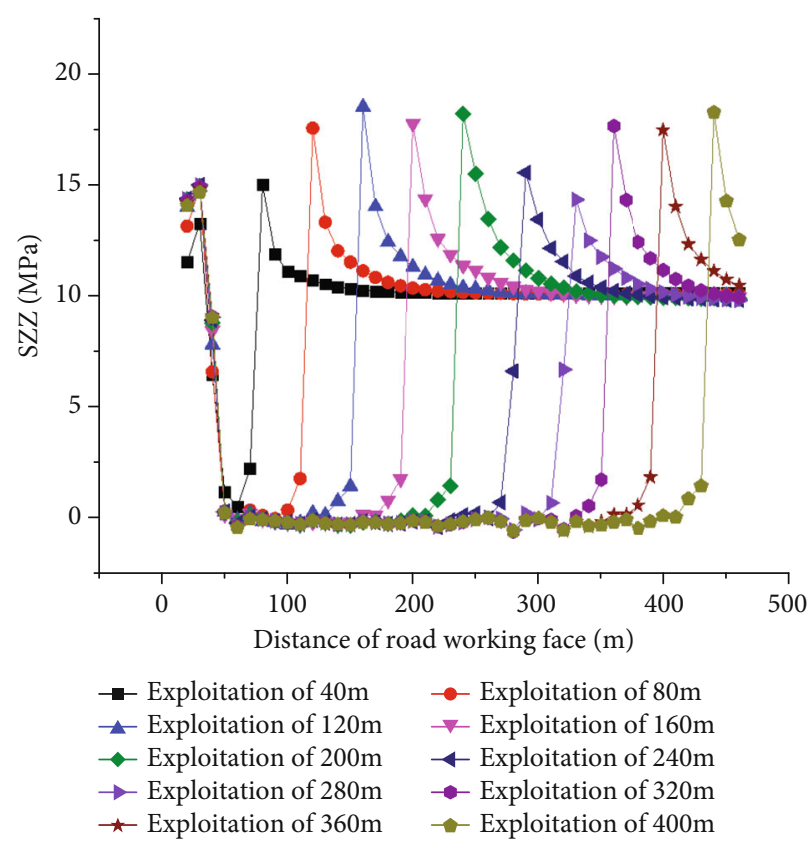

FIGURE 7: Variation curve of vertical stress of surrounding rock of E9103 workface at different advancement distances.

\section{Failure Characteristics of Overburden Rock during Mining in an Inclined Coal Seam}

After workface mined, the damage on the overlying strata of the stope presents obvious zonation. In accordance with the theory of mine pressure and strata control, the overlying strata of the workface after mining generally form caving, fissure, and bending subsidence zones from the bottom to the top, in which the height of the development of the falling and fissure zones (called "two-zones" parameter) is an important technical parameter for safe production of the workface. The distribution form and development height of overlying strata of the stope are closely related to the geological conditions of the workface and essential in guiding the prevention and control of water hazards. In the following part, the development characteristics of the "two-zones" of overlying strata in E9103 inclined coal seam workface are analyzed from two perspectives, namely, plastic failure characteristics of overlying strata and stress discrimination method.

5.1. Distribution Characteristics of the Plastic Zone of Stope Overburden. After yielding, the overlying strata of the stope enter a plastic state, and their integrity is destroyed. On the one hand, the inherent cracks in the rock mass further expand and extend; on the other hand, new cracks are generated. These cracks connect with each other and form a water conduction crack passage. The failure characteristics of the plastic zone of the overlying strata can intuitively reflect the failure form, which is one of the main bases for analyzing the development height of the "two-zones" of the overlying strata and for determining the height of the maximum water conduction fissure zone. A distribution 


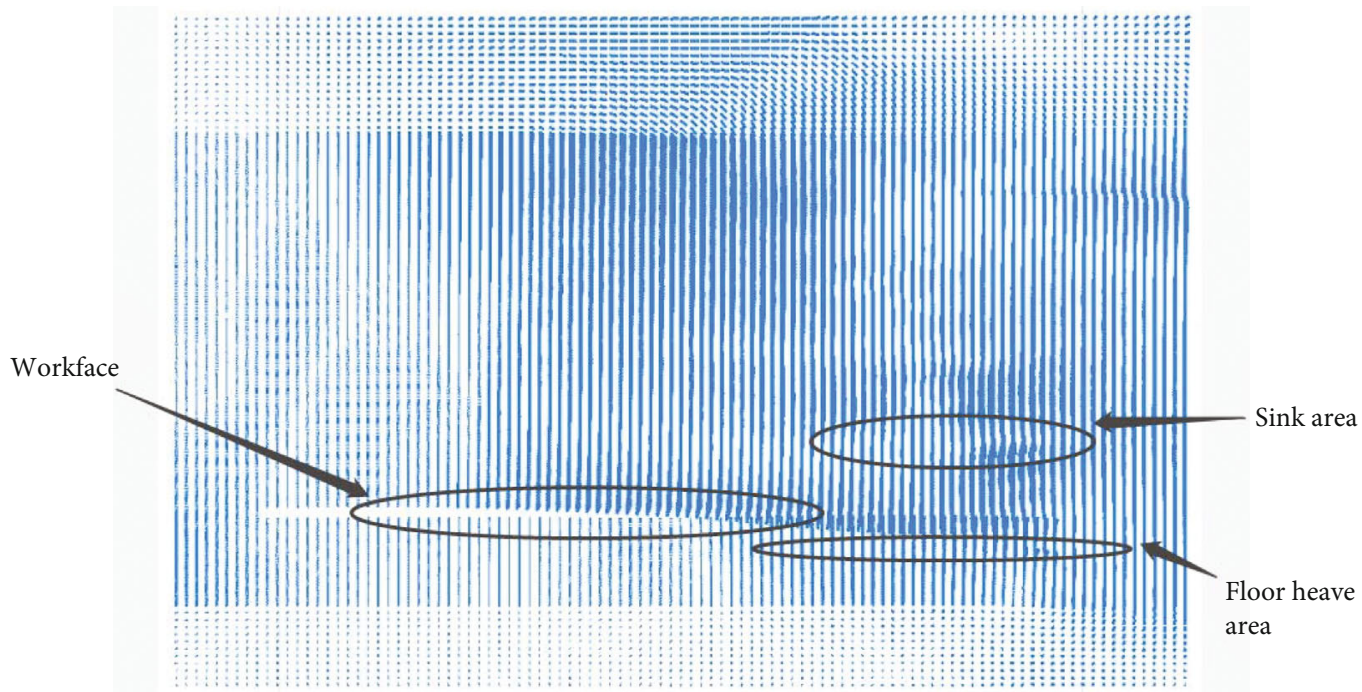

FIGURE 8: Vector distribution of overburden displacement of overlying strata when E9103 workface advances to $400 \mathrm{~m}$.

cloud diagram of the plastic zone of overlying strata in the direction of the strike and inclination of the workface when the E9103 workface is advanced to $400 \mathrm{~m}$ is shown in Figure 10.

The distribution cloud diagram of the plastic area of the overlying strata shows that the rock in the goaf is mainly caused by tensile and shear failure then by shear failure upward. The overlying strata after mining can be roughly divided into five deformation and destruction areas from top to bottom; the five are nondestroyed area, plastic deformation area, tension crack area, tension damage area, and local tension area. The failure form of the overlying strata is a symmetrical "arched" distribution along the advancing direction of the workface; it is also an asymmetrical "arched" distribution along the inclined direction of the coal seam, and the broken vault deviates from the middle to the upper part of the workface. The failure form of the overlying strata along the inclined direction of the coal seam is completely different from that along the workface of the horizontal coal seam. After coal seam mining, the height of the fissure zone of the overlying strata of the stope is mainly affected by the range of plastic zones above the coal and rock mass and above the goaf before and after the workface. Rocks in the caving zone are generally in the localized tension zone, and the plastic zone is mainly characterized by tension failure. Figure 10 shows that the height of the caving and water conduction fissure zones of the workface is 18.13 and $62.2 \mathrm{~m}$, respectively (the maximum height of the plastic zone).

5.2. Failure Characteristics of the "Two-Zones" of Overlying Strata. The stress discrimination method is adopted to calculate the stress of each joint by using different strength and yield criteria and to judge whether the point has yielded failure by using the stress state of the joint. Tensile stress and small compressive stress zones are areas where cracks develop. The upper bounds of tension failure and tension fracture zones are important criteria for determining the height of the caving and water conduction fracture zones. Figure 11 shows a sketch of the maximum principal stress, minimum principal stress, and horizontal stress of the overlying strata of the stope when the E9103 workface is advanced to $400 \mathrm{~m}$.

The principal stress nephograms in Figures 11(a) and 11(b) show that the maximum principal stress distribution is similar to that of the saddle and basically consistent with that of the plastic zone. The minimum principal stress develops upward in the form of an arch. The horizontal stress nephograms in Figures 11(c) and 11(d) show that the vertical zone of horizontal stress of the overlying strata of the stope is obvious. Tensile stress occurs in a certain range over the goaf. The tensile stress gradually transforms into compressive stress, and the horizontal stress isoline becomes sparse after exceeding the range. According to the magnitude and nature of horizontal and principal stresses, it can be divided into three zones, namely, bidirectional tension stress zone, tension-compression stress zone, and compression stress zone. The bidirectional tensile stress area shows that the maximum and minimum principal stresses are greater than 0 , which is mainly distributed in the strata of the caving zone in the goaf. When the tensile stress exceeds the ultimate tensile strength of the rock mass, the rock mass breaks and collapses, and the stress is released and transferred. The tensile and compressive stress areas show that the maximum principal stress is greater than 0 , and the minimum principal stress is less than 0 , which is mainly distributed outside the rock mass of the caving zone, and the rock mass is subject to a certain direction of tensile stress. When the compressive stress is higher than the tensile strength, shear and tensile fractures are produced. The compressive stress zone shows that the maximum and minimum principal stresses are less than 0 . The caving zone is generally located in the bidirectional tensile stress zone and tension-compression stress zone of the overlying strata. The main failure forms are tension and shear failures. The 


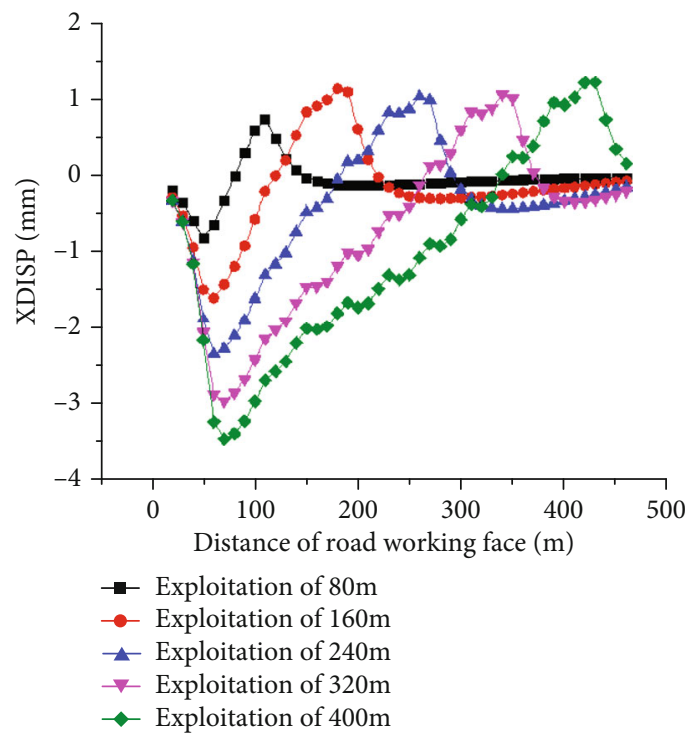

(a) $x$-direction

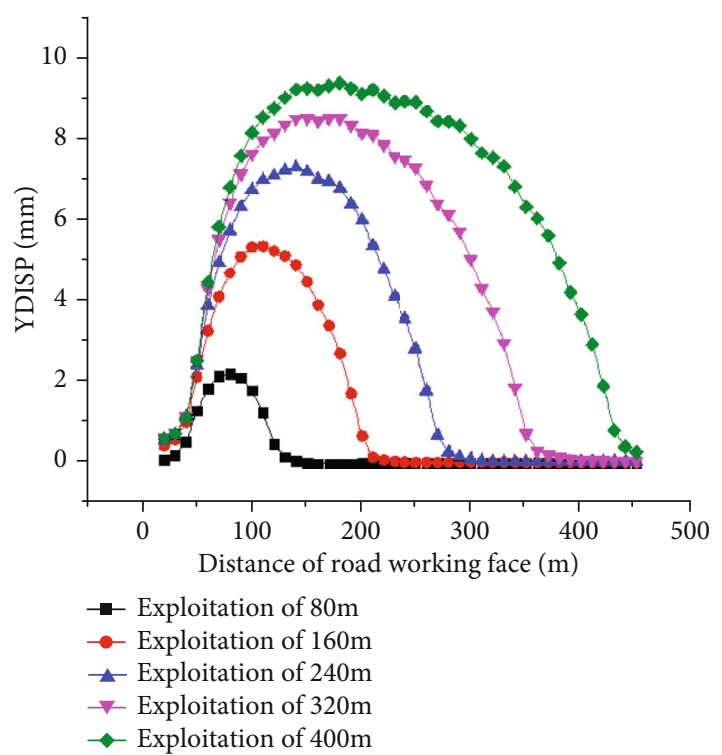

(b) $y$-direction

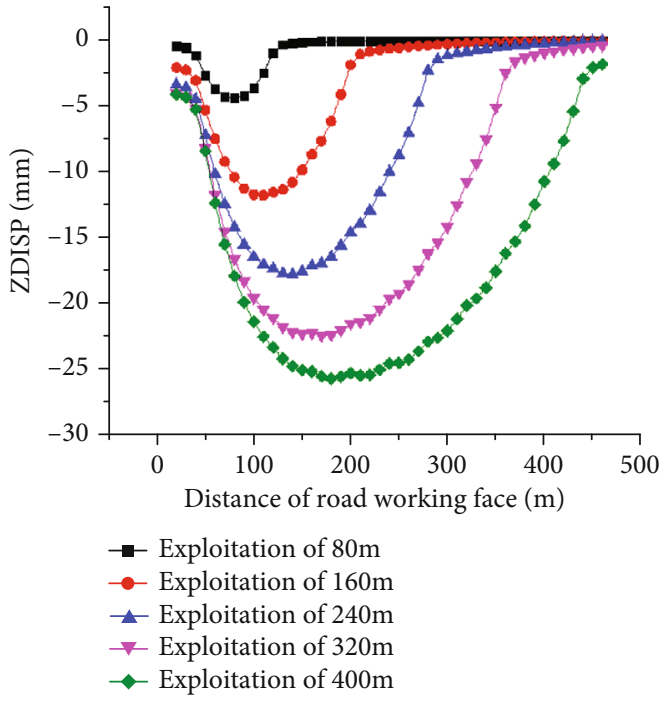

(c) $z$-direction

Figure 9: Variation curves of horizontal displacement ( $x$-direction and $y$-direction) and vertical displacement ( $z$-direction) of overburden of E9103 workface at different advancement distances.

magnitude of principal stress and rock mass properties controls the development height of the caving zone and the openness, density, and penetration of mining cracks.

Rock is a compressive and non-tensile material. Generally, if the maximum and minimum principal stresses of the overlying strata in the goaf are tensile stresses, the rock will experience comprehensive tensile failure, and the roof will fall to form a caving zone. If only one of the principal stresses is tensile stress, visible cracks will occur perpendicular to the tensile stress, forming a fractured zone. The positive tensile stress is set, the main stress of the overlying strata is taken as the range of tensile stress of the caving zone, and the range of the main stress in one direction is adopted as the height of the obvious fissure zone. Figure 12 shows the variation in the development height of the caving and fracture zones of the overlying strata of E9103 workface at different advancing distances. Figure 12 indicates that when the workface is advanced for $40 \mathrm{~m}$, the heights of the caving and fracture zones are 7.2 and $30.8 \mathrm{~m}$, respectively. When the workface is advanced for $80 \mathrm{~m}$, the height of the caving zone is $8.5 \mathrm{~m}$, and the height of the fracture zone is $40.5 \mathrm{~m}$. When the workface is advanced for $120 \mathrm{~m}$, the heights of the caving and fracture zones are 10.82 and $47.3 \mathrm{~m}$, respectively. When the workface is advanced for $160 \mathrm{~m}$, the height of the caving zone is $12.5 \mathrm{~m}$, and the height of the fracture zone is $52.1 \mathrm{~m}$. When the workface is advanced for $200 \mathrm{~m}$, the heights of the caving and fracture zones are 14.18 and $56.11 \mathrm{~m}$, respectively. When the workface is advanced for $240 \mathrm{~m}$, the heights of the caving and fracture zones are 15.62 and $57.34 \mathrm{~m}$, respectively. When the workface is advanced for $280 \mathrm{~m}$, the height of the caving zone is $16.91 \mathrm{~m}$, and the height of the fracture zone is $58.2 \mathrm{~m}$. 


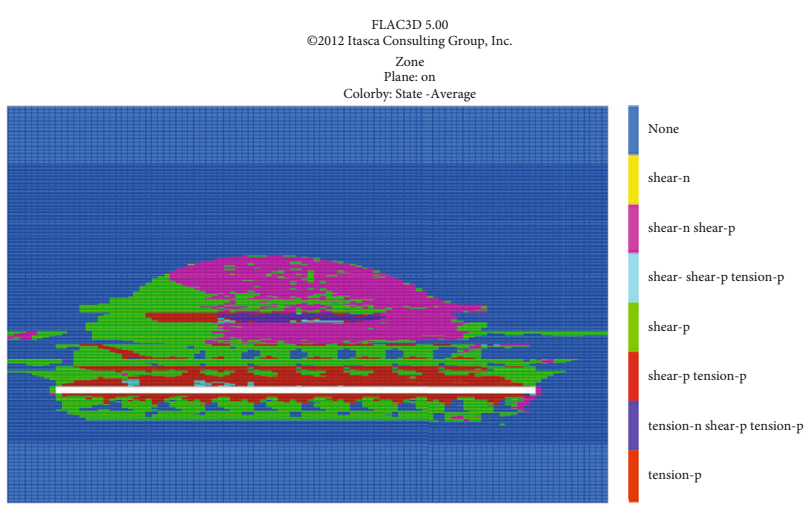

(a) Advanced direction of workface

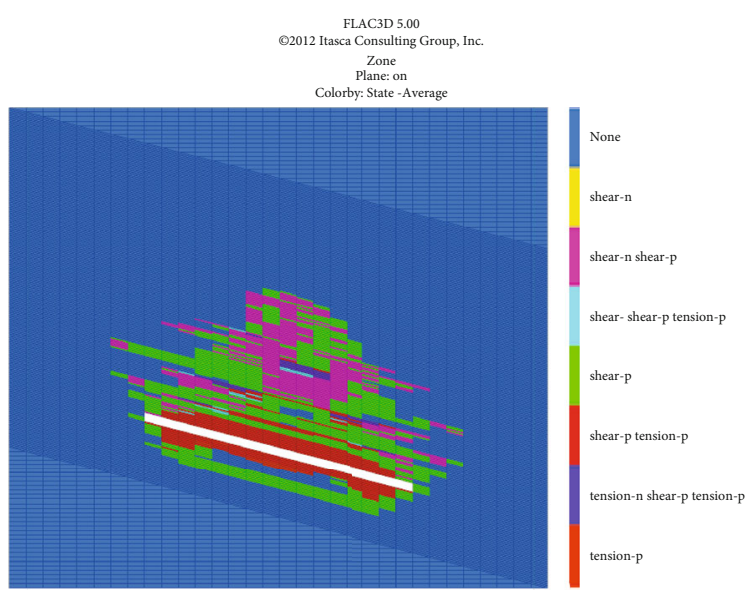

(b) Inclined direction of workface

FIgURE 10: Cloud diagram of workface orientation and inclination plasticity zone distribution as E9103 workface advances to $400 \mathrm{~m}$.

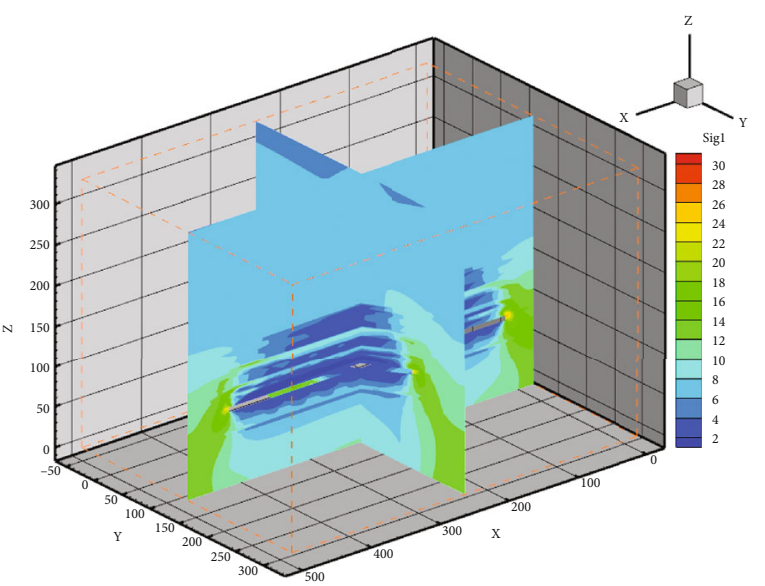

(a) Maximum principal stress

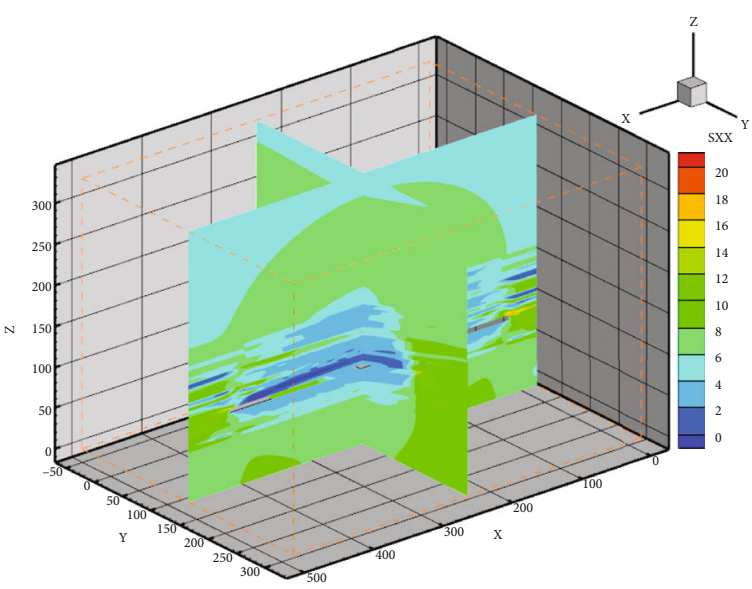

(c) Horizontal stress SXX

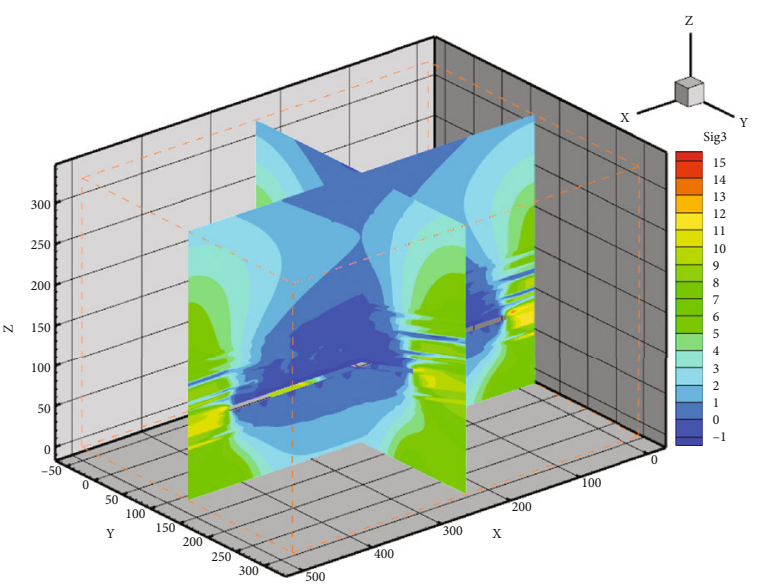

(b) Minimum principal stress

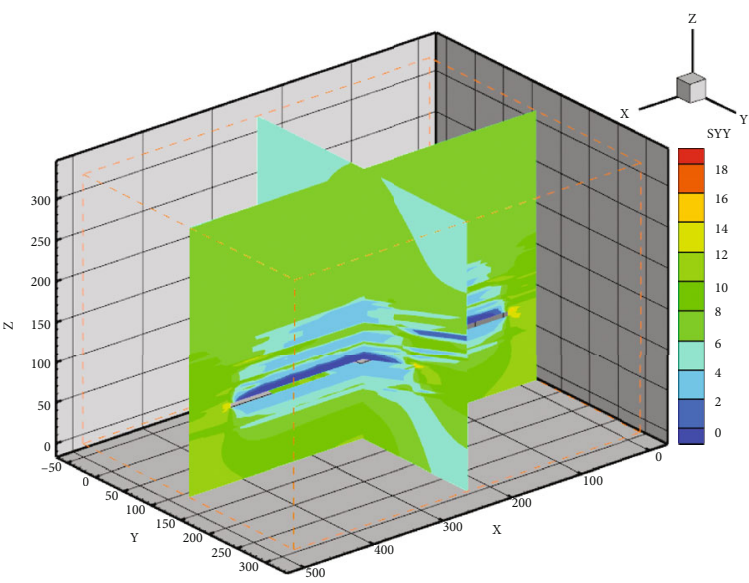

(d) Horizontal stress SYY

FIGURE 11: Cloud diagrams of maximum principal stress, minimum principal stress, and horizontal stress of overlying strata when E9103 workface advanced to $400 \mathrm{~m}$.

When the workface is advanced for $320 \mathrm{~m}$, the height of the caving zone is $15.88 \mathrm{~m}$, and the height of the fracture zone is $59.1 \mathrm{~m}$. When the workface is advanced for $360 \mathrm{~m}$, the heights of the caving and fracture zones are 17.61 and $59.8 \mathrm{~m}$, respectively. When the workface is advanced for $400 \mathrm{~m}$, the heights of the caving and fracture zones are 


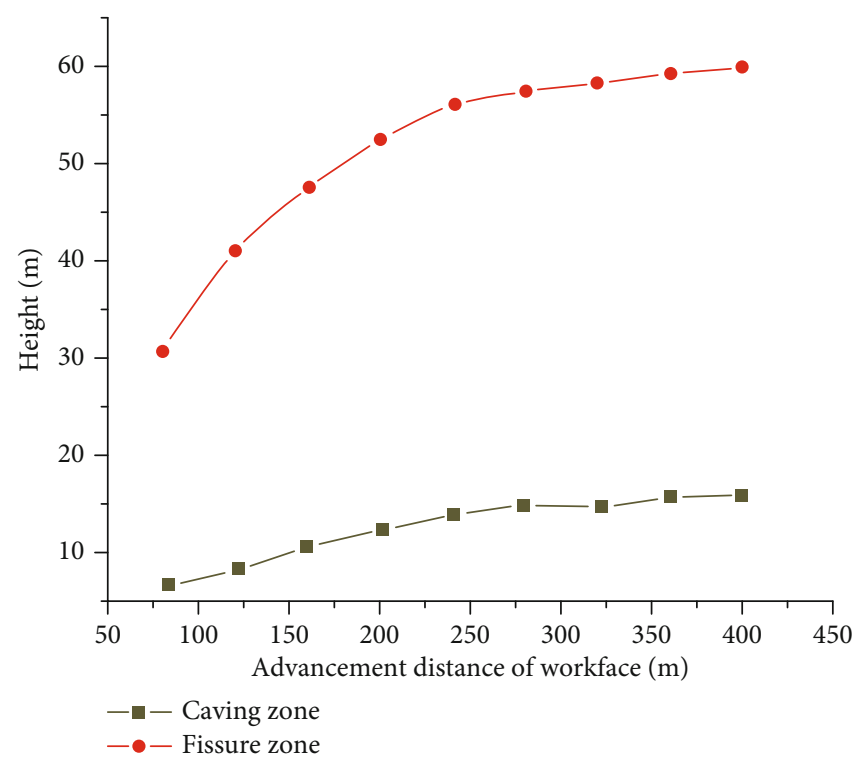

Figure 12: Development height of the overlying strata of caving zone and fissure zone at different advancement distances of E9103 workface.

18.13 and $62.2 \mathrm{~m}$, respectively. In conclusion, the height of the overburden caving zone has little to do with the advancing distance of the E9103 workface; it increases slowly with the advancing distance of the workface, and the height of the caving zone is $7.2-18.13 \mathrm{~m}$. The height of the fracture zone increases rapidly with the advancing distance of the workface. It tends to be flat when the advancing distance is equal to the length of the workface and remains at a stable level; the development height of the fracture zone is $30.8-62.2 \mathrm{~m}$.

\section{Conclusions}

On the basis of the hydrogeological data of the E9103 workface in Hengiin Coal Mine, a numerical calculation model of the overlying strata of the E9103 inclined coal seam workface was established by applying FLAC numerical simulation software. The stress distribution and failure characteristics were simulated and analyzed, and the development heights of the caving and water conduction fissure zones of the E9103 workface were confirmed. The following main conclusions were obtained:

(1) After the E9103 workface is mined, stress reduction zones emerge above the goaf, and these are in the form of "arches." Tension stresses occur in the local area of the overlying strata. The relief arch of the overlying strata is symmetrically distributed along the advancing direction of the E9103 workface, asymmetrically distributed along the inclined direction, and its arch is inclined above the workface

(2) The horizontal and vertical displacements of the overlying strata of the E9103 workface increase with advancing distance. The horizontal displacement in the $x$-direction presents two obvious areas, and the critical point of both areas moves forward with the workface, showing a certain symmetry. The horizontal displacement in the $y$-direction presents an "inverted bowl" distribution and increases with the advancement of the workface

(3) The overlying strata in the E9103 workface are mainly tensile and tensile-shear failure and then upward shear failure. The overlying strata in the caving zone are generally in the local tension area, and the plastic zone is mainly tension failure. The height of the caving zone in the E9103 workface has little relationship with advancing distance, and it increases slowly with advancing distance. The development height of the caving zone is 7.2$18.13 \mathrm{~m}$. The development height of the water conduction fissure zone increases rapidly with advancing distance. When the advancing distance is equal to the length of the working face, the development height of the fissure zone is flat and basically maintains a stable value. The development height of the water conduction fissure zone is $30.8-62.2 \mathrm{~m}$

\section{Data Availability}

Without any supplementary materials for this study, all the data, tables, and pictures have been presented in the paper.

\section{Conflicts of Interest}

The authors declare that they have no conflicts of interest regarding the publication of this paper.

\section{Acknowledgments}

This study was supported by the National Natural Science Foundation of China (no. 51974010). 


\section{References}

[1] M. Qian and P. Shi, Ground Pressure and Strata Control, China University of Mining \& Technology Press, Xuzhou, China, 2003.

[2] X. Zhang Pingsong, G. L. Shiang, and W. Rongxin, "Prospect and progress of deformation and failure monitoring technology of surrounding rock in stope," Coal Science and Technology, vol. 48, no. 3, pp. 14-35, 2020.

[3] Z. Dan, Z. Pingsong, S. Bin, W. Hongxian, and L. Changsheng, "Monitoring and analysis of overburden deformation and failure using distributed fiber optic sensing," Chinese Journal of Geotechnical Engineering, vol. 37, no. 5, pp. 952-957, 2015.

[4] L. Jia, X. Yi, C. Wei, H. Peng, W. Songhe, and L. Xin, "Variational phase-field model based on lower-dimensional interfacial element in FEM framework for investigating fracture behavior in layered rocks," Engineering Fracture Mechanics, vol. 255, article 107962, 2021

[5] Y. Xue, T. Teng, F. Dang, Z. Ma, S. Wang, and H. Xue, "Productivity analysis of fractured wells in reservoir of hydrogen and carbon based on dual-porosity medium model," International Journal of Hydrogen Energy, vol. 45, no. 39, pp. 20240-20249, 2020.

[6] State Bureau of Coal Industry, Regulations of Buildings, Water, Rail Way and Main Well Lane Leaving Coal Pillar and Press Coal Mining, China Coal Industry Publishing House, Beijing, 2000.

[7] H. Bingxiang, X. Liu Changyou, and Jialin, "Research on through degree of overlying strata fracture fissure induced by mining," Journal of China University of Mining \& Technology, vol. 39, no. 1, pp. 45-49, 2010.

[8] L. Yu, L. Qimeng, L. Wenping, and H. Youbiao, "Height of mining-induced fractured zones in overlying strata and permeability of rock with nonpenetrative fractures," Geofluids, vol. 2020, 13 pages, 2020.

[9] C. Xianggang, Q. Wei, L. Li, J. Chuanwen, and N. Lei, "Model of mining-induced fracture stress-seepage coupling in coal seam over-burden and prediction of mine inflow," Journal of China Coal Society, vol. 45, no. 8, pp. 2890-2900, 2020.

[10] S. Jian, W. Lianguo, and Z. Guangming, "Stress distribution and failure characteristics for workface floor of a tilted coal seam," KSCE Journal of Civil Engineering, vol. 23, no. 9, pp. 3793-3806, 2019.

[11] W. Cheng, Z. Nong, X. Li Guichen, Q. D. Xingliang, and Z. Nianchao, "Control principles for roadway roof stabilization in different zones during ascending mining," Journal of China University of Mining \& Technology, vol. 41, no. 4, pp. 543-550, 2012.

[12] Z. Wei, Z. Dongsheng, C. Jianben, X. Wang Xufeng, and Mengtang, "Determining the optimum gateway location for extremely close coal seams," Journal of China University of Mining \& Technology, vol. 2, pp. 182-188, 2012.

[13] Z. Shizhong, F. Gangwei, C. Ling et al., "Disaster control of roof falling in deep coal mine roadway subjected to high abutment pressure," Geofluids, A. Brogi, Ed., vol. 2021, Article ID 8875249, 17 pages, 2021.

[14] W. Xinfeng, G. Mingzhong, and L. Longqin, "Spatiotemporal coupling law of mining pressure, strata movement and fracture field distribution in deep stope," Journal of Mining \& Safety Engineering, vol. 33, no. 4, pp. 604-610, 2016.

[15] H. Wanpeng, X. Wenbin, Z. Yongsheng, and L. Chao, "Reasonable layout of roadways for upward mining technology of close coal seams," Chinese Journal of Rock Mechanics and Engineering, vol. 36, no. 12, pp. 3028-3039, 2017.

[16] L. Xingping, C. Feng, C. Jiantao, L. Zhaohai, and Y. Lei, "Analysis on characteristics of overlying rock caving and fissure conductive water in top-coal caving working face at three soft coal seam," Journal of China Coal Society, vol. 42, no. 1, pp. 148-154, 2017.

[17] Y. Daming, G. Wenbing, Z. Gaobo, T. Yi, and Y. Weiqiang, "Height of water-conducting zone in longwall top-coal caving mining under thick alluvium and soft overburden," Journal of China Coal Society, vol. 44, no. 11, pp. 3308-3316, 2019. 